\title{
The role of total fats, saturated/unsaturated fatty acids and cholesterol content in chicken meat as cardiovascular risk factors
}

\author{
Dragan Milićević ${ }^{*}$, Danijela Vranić ${ }^{1}$, Zoran Mašić ${ }^{2}$, Nenad Parunović ${ }^{1}$ Dejana Trbović ${ }^{1}$ \\ Jelena Nedeljković-Trailović ${ }^{3}$ and Zoran Petrović ${ }^{1}$
}

\begin{abstract}
Background: The objective of the study was to present information about the chemical composition, the fatty acids profile, and cholesterol content of chicken meat in order to investigate the impact of chicken meat consumption on cardiovascular risk in the general population.

Methods: A total of 48 6-wk-old broiler chickens broilers from two farms in June to November of 2012, and February of 2013, were used in this trial. Total lipid content was determined by extraction of fat by petrol ether (Soxhlet) after acid hydrolysis of samples. Fatty acids were determined by capillary gas chromatography. Cholesterol determination was performed by using HPLC/PDA system.

Results: The results indicate that the total free cholesterol content in raw breast and drumstick of chickens was in the range of 37,41-79,9 mg/100 $\mathrm{g}$ and 48,35-99,5 mg/100 g, respectively. The main fatty acids identified in all cuts were C18:1C9, C18:2n6, C16:0, C18:0, and C16:1. Decreasing the dietary n-6/n-3 clearly decreased the content in breast and drumstick muscle of C18:2n6, C18:3n3, and C20:3n6, but increased that of C16:0, C18:0, and C20:2. Also, the major saturated fatty acid (SFA) (C16:0 and C18:0) was significantly differ among the four treatments.

Conclusion: Our study shows that dietary fat and fatty acid composition influence the concentrations of total cholesterol content, total fat content, and fatty acid composition in broiler muscle. This information will aid in determining the burden of chicken meat as a cardiovascular risk factors disease and act as a planning tool for public-health Programmes.
\end{abstract}

Keywords: Chicken meat, Cholesterol, Fatty acids, Cardiovascular risk

\section{Background}

In the human diet, meat is seen as a major source of fat, and especially of saturated fatty acids (SFAs), which have been implicated in diseases associated with modern life, mostly in developed countries. Coronary heart disease and arteriosclerosis are among the most important causes of human mortality, and are strongly associated with dietary intake of cholesterol and saturated fatty acids $[1,2]$. In addition, a strong relationship has been demonstrated between cellular cholesterol concentration and Alzheimer's disease [3]. The World Health Organization [4]

\footnotetext{
* Correspondence: dragan@inmesbgd.com

${ }^{1}$ Institute of Meat Hygiene and Technology, Kaćanskog 13, 11040 Belgrade, Serbia

Full list of author information is available at the end of the article
}

recommends that the daily fat intake be reduced to $30 \%$ of the total energy intake, and that saturated fats should be limited to $10 \%$ of this caloric intake. It is also advised that cholesterol intake should not exceed $300 \mathrm{mg}$ per day.

Dietary intake of unsaturated fatty acids (UFA) has been shown to reduce the risk of cardiovascular disease (CVD) and possibly the incidence of some cancers, asthma and diabetes among other conditions. At the same time, the recommended ratio of polyunsaturated fatty acids (PUFAs) to SFAs (P/S) should be above 0.4, with the normal P/S ratio of meat at around 0.1 [5]. The ratio of $n-6 / n-3$ PUFAs is considered to be a risk factor in cancers and coronary heart disease, and it is recommended that this ratio be less than 4.0 [6]. Achieving a better balance of fatty acids in the diet, by decreasing 
intakes of cholesterol and saturated fats, is therefore seen as an important and effective strategy by which to reduce the incidence of these diseases. Therefore, the knowledge on the cholesterol content in food is important, especially in poultry and fish meat, because the consumption of these foods is currently increasing based on the recommendations of healthy nutrition.

The objective of the present study was to present information about the cholesterol content fat content and $n-6 / n-3$ ratio of chicken meats in order to estimate whether the expected health effects of the former are potentially the same as those of the latter, especially in relation to cardiovascular diseases. In an array of data regarding cholesterol content and fatty acid composition of meat, the new contribution of the study can be seen in the following aspects: cholesterol content and fatty acid composition of the animal tissues can be influenced by the composition of the feed mixtures, especially by the ratio of polyunsaturated fatty acids [7].

\section{Results}

\section{Carcass quality}

The physicochemical properties and quality characteristics of chicken meat, reared under standard condition are presented in Table 1.
The results from physicochemical properties and quality characteristics in the current study are consistent with previous results from the same laboratory. Diets had no effect on meat sensory attributes (data not presented). Comparing the meat quality characteristics among treatments (farms), significant differences were found for all parameters except for Fe content in drumstick. Dark meat was found to contain slightly more than twice as much Iron as white meat $(8.42 \pm 1.46$ vs $3.94 \pm 0.42 \mathrm{mg} / \mathrm{kg})$, respectively. The means for total iron reported in this study for both white (breasts) and dark (drumsticks) chicken meat, are similar to the 5 and $10 \mathrm{mg} / \mathrm{kg}$ reported by McCance et al. [8]. The $\mathrm{pH}$ at 24 hours post-mortem on the treatment I in summer period had a significantly lower $(\mathrm{P}<0,001) \mathrm{pH}$ than birds from other farms. In Breast $\mathrm{pH}$ was $5.40 \pm 0.20$ versus $5.90 \pm 0.11,5.88 \pm 0.18$ versus $5.84 \pm 0.14$ while in Drumstick was $5.71 \pm 0.30$ versus $6.44 \pm 0.17,6.45 \pm 0.26$ versus $6.51 \pm 0.09$. These results show that the $\mathrm{pH}$ values of pale samples were $5.40 \pm 0.20$ and $5.71 \pm 0.30$, respectively. Meat products with low $\mathrm{pH}$ values are associated with poor water-holding capacity and meat color $[9,10]$. These results are in agreement with those reported by Vimini, (1996) [11] and Barbut (1998) [12] in which the incidence of PSE-quality broiler breast meat varies from 2 to $20 \%$, depending on the

Table 1 Physicochemical properties and quality characteristics of chicken meat between farms during two period of investigation $(\overline{\mathbf{X}} \pm \mathrm{Sd})$

\begin{tabular}{|c|c|c|c|c|c|}
\hline \multirow[t]{2}{*}{ Parameter } & & \multicolumn{4}{|c|}{ Tretman } \\
\hline & & $I^{a}$ & $I^{a}$ & $\mathbf{l}^{\mathbf{b}}$ & $I I^{b}$ \\
\hline Average live weight (g) & & $2190^{a}$ & $1470^{b, a}$ & $2240^{b, e}$ & $2220^{b, f}$ \\
\hline Age at slaughter (d) & & 38 & 38 & 39 & 38 \\
\hline Carcass weight (g) & & $1279,45 \pm 174,02$ & $1223,3 \pm 116,38$ & $1764,87 \pm 227,83$ & $1400,70 \pm 130,01$ \\
\hline \multirow[t]{2}{*}{ Weight (g) } & Breast & $452,5 \pm 80,17$ & $427,70 \pm 53,44$ & $647,95 \pm 78,70$ & $470,62 \pm 61,15$ \\
\hline & Drumstick & $389,89 \pm 51,19$ & $392,9 \pm 39,20$ & $536,40 \pm 88,41$ & $476,78 \pm 48,20$ \\
\hline \multirow[t]{2}{*}{ pH, Ultimate } & Breast & $5,4 \pm 0,20^{a}$ & $5,90 \pm 0,11^{b}$ & $5,88 \pm 0,18^{b}$ & $5,84 \pm 0,14^{b}$ \\
\hline & Drumstick & $5,71 \pm 0,30^{a}$ & $6,44 \pm 0,17^{b}$ & $6,45 \pm 0,26^{b}$ & $6,51 \pm 0,09^{b}$ \\
\hline \multirow[t]{2}{*}{ Water-holding capacity (\%) } & Breast & $30,53 \pm 7,27^{e}$ & $29,44 \pm 10,95^{c}$ & $36,58 \pm 7,70^{d}$ & $42,78 \pm 10,93^{f, d}$ \\
\hline & Drumstick & $17,04 \pm 5,60^{a}$ & $26,50 \pm 9,81^{b, c}$ & $31,60 \pm 7,82^{b}$ & $37,94 \pm 9,83^{b, d}$ \\
\hline \multirow[t]{2}{*}{ Moisture (\%) } & Breast & $71,25 \pm 2,75$ & $70,74 \pm 3,79^{a}$ & $71,48 \pm 2,58$ & $74,29 \pm 1,32^{b}$ \\
\hline & Drumstick & $69,50 \pm 1,40^{a}$ & $71,765 \pm 1,78$ & $71,13 \pm 0,63^{b}$ & $72,29 \pm 2,81$ \\
\hline \multirow[t]{2}{*}{ Protein (\%) } & Breast & $21,18 \pm 0,96^{\mathrm{e}}$ & $21,65 \pm 0,75$ & $22,18 \pm 0,25^{f}$ & $22,29 \pm 0,71$ \\
\hline & Drumstick & $17,95 \pm 0,956$ & $18,68 \pm 0,96$ & $18,41 \pm 0,95$ & $17,92 \pm 0,61$ \\
\hline \multirow[t]{2}{*}{ Lipids (\%) } & Breast & $5,53 \pm 0,61^{a}$ & $3,05 \pm 1,11^{b, c}$ & $4,19 \pm 1,15^{b, d, e}$ & $2,61 \pm 0,77^{b, f}$ \\
\hline & Drumstick & $9,63 \pm 0,63^{a}$ & $5,19 \pm 0,45^{b, a}$ & $9,85 \pm 1,98^{b}$ & $8,16 \pm 2,25^{b}$ \\
\hline \multirow[t]{2}{*}{ Ash (\%) } & Breast & $0,99 \pm 0,13^{a}$ & $1,16 \pm 0,09^{b, e}$ & $1,04 \pm 0,09^{f, a}$ & $1,29 \pm 0,11^{b, f}$ \\
\hline & Drumstick & $0,92 \pm 0,05^{f}$ & $1,026 \pm 0,05^{f, a}$ & $0,91 \pm 0,06^{b, a}$ & $1,01 \pm 0,07^{f, b}$ \\
\hline \multirow[t]{2}{*}{ Fe total (mg/kg) } & Breast & $4,06 \pm 1,36$ & $4,34 \pm 0,55^{d}$ & $3,94 \pm 0,42^{c}$ & $4,29 \pm 0,31^{d}$ \\
\hline & Drumstick & $7,88 \pm 1,41$ & $7,45 \pm 0,98$ & $8,42 \pm 1,46$ & $8,12 \pm 0,68$ \\
\hline
\end{tabular}

$\mathrm{n}=12$ per Tretman, ${ }^{\text {a:b }} \mathrm{p}<0,001,{ }^{\text {c:d }} \mathrm{p}<0,05,{ }^{\text {e.f }} \mathrm{p}<0,01$, (Tretman-Farm I and II), a-summer, b- winter. 
environmental conditions. In the current study, a higher ultimate $\mathrm{pH}$ value was found in drumstick in the three farms and were $6.44 \pm 0.17,6.45 \pm 0.26$ and $6.51 \pm 0.09$, respectively. Water-holding capacity, reported as percentage expressible juice, was $30.53 \pm 7.27 \%$ and $17.04 \pm$ $5.60 \%$ of the PSE samples, $29.44 \pm 10.95-42.78 \pm 10.93 \%$ of the normal samples, and $26.50 \pm 9.81-37.94 \pm 9.83 \%$ of the dark samples. There were very low level of negative or positive correlations between $\mathrm{pH}$ and WHC $(-0.280$ to $0,245)$, except in one case where moderate positive correlation between $\mathrm{pH}$ and WHC (0.401) was recorded.

\section{Cholesterol concentration}

The cholesterol concentrations of raw drumstick and breast muscles are presented in Figure 1A.
Breast muscle showed lower values, possibly because of its lower fat content. The cholesterol content in Breast meat in the present study varied from 37.41 to $79.9 \mathrm{mg} / 100 \mathrm{~g}$, while in Drumstick varied from 48.35 to $99.5 \mathrm{mg} / 100 \mathrm{~g}$ in depend on treatments. As shown in this study, the magnitude of variation of the cholesterol contents in muscles appears to be high (Figure 1A). Thus, significant differences $(\mathrm{P}<0.001)$ in content of cholesterol were observed among farms. The cholesterol levels in chicken meat values presented in this paper are generally within the ranges of the published data [13-17]. In general, raw poultry meat has approximately 27 to $90 \mathrm{mg}$ cholesterol/100 g and cooked poultry meat contains around 59 to $154 \mathrm{mg} / 100 \mathrm{~g}[14,16]$. In addition, the difference between chicken breast fillet
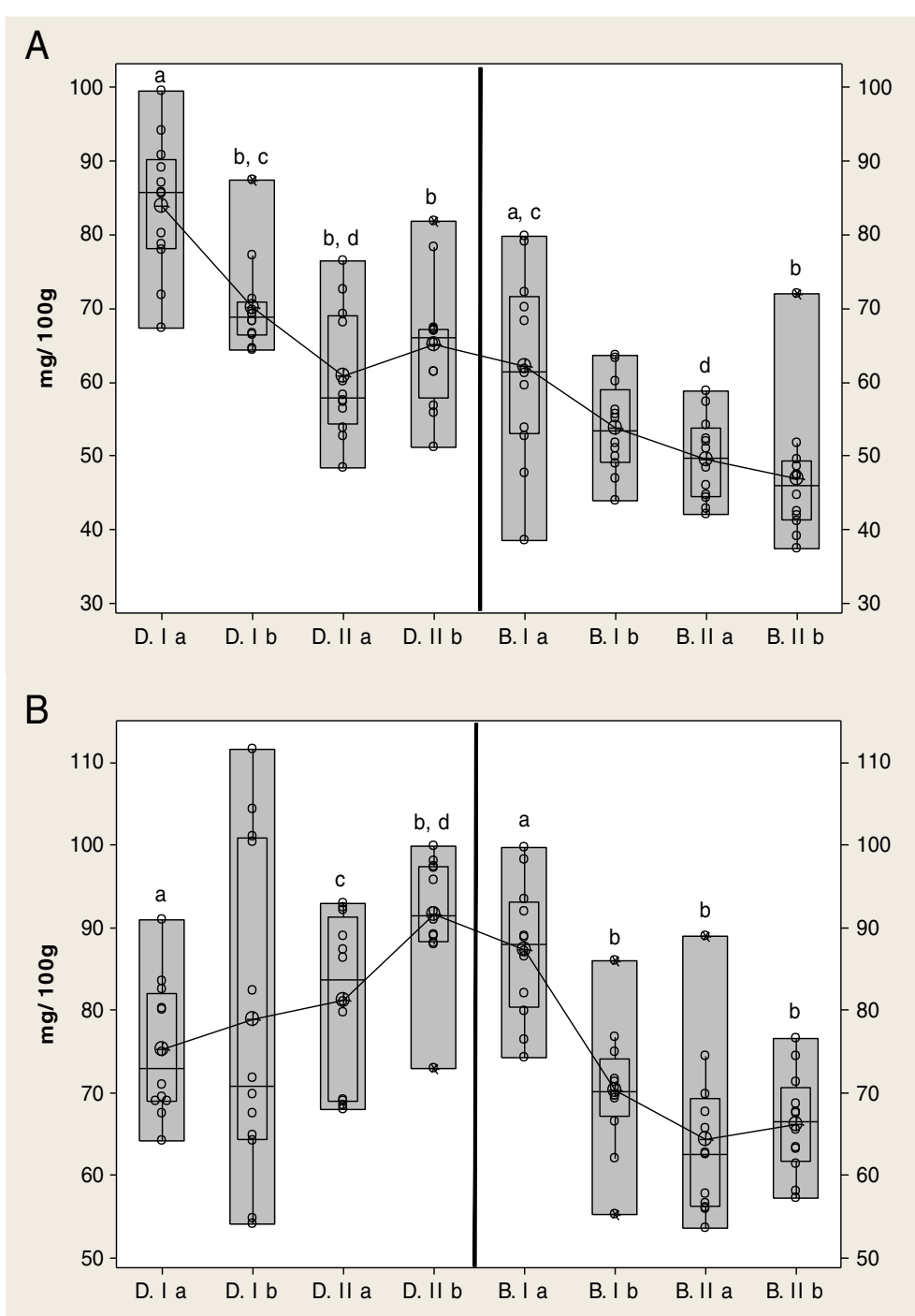

Figure 1 Content of cholesterol in Raw (A) and Heat (B) processed Breast and Drumstick muscle between farms during two period of investigation (D.-Drumstick, B.- Breast muscle, I, II-farm, a Summer, b Autumn/winter period) ${ }^{a: b} p<0,001{ }^{b: c} p<0,01$. 
and leg and thigh is of the same magnitude seen in other studies.

Fatty acid composition of breast and drumsticks muscle The fatty acid profile of breast and drumsticks muscle are presented in Tables 2 and 3 .

The main fatty acids identified in both the muscles were monounsaturated fatty acid (MUFA) oleic acid (C18:1c9), and highest levels (42.85\%) were observed in meat of chicken from farm Ia. In breast muscles, the major saturated fatty acid (SFA) was palmitic acid (16:0) and ranged from $21.35 \%$ to $28.53 \%$; and the major polyunsaturated fatty acid (PUFA) was linoleic acid (C18:2n6) and varied from $10.26 \%$ to $24.85 \%$. The fatty acid profile of the drumstick muscles, showed a slightly higher fraction of PUFA (C18:2n6) in comparison to SFA (16:0). Although the PUFA/SFA ratio was similar for the four diet groups, $n-6 / n-3$ ratio of meat were significantly different $(\mathrm{P}<0.001)$ between the samples analyzed. This is due to the predominance of corn, soy and sunflower oils the source of fat, which is high in n- 6 fatty acids. Comparing breast with drumsticks muscle, the breast contained more SFA, and n-3 PUFA, but less MUFAs, total PUFAs and n-6 PUFA. This effect has been reported by Lopez-Ferrer et al. (1999) [18].

\section{Roasted meat}

The cholesterol concentrations of roasted drumstick and breast muscles are presented in Figure 1B.

The concentration of cholesterol was greater in roasted than in raw meat. The increase in cholesterol correlated well with the observed loss in weight due to water evaporation during roasted (data not shown). The values obtained for the cholesterol varied considerably between samples and between muscles, and thus the values are presented separately (Figure 1B). The drumsticks showed the highest amount, whereas the breast meat presented the lowest values. The cholesterol content

Table 2 Fatty Acids Composition (mg/100 g) of Breast muscle $(\overline{\mathrm{X}} \pm \mathrm{Sd})$

\begin{tabular}{|c|c|c|c|c|}
\hline \multirow{2}{*}{$\begin{array}{l}\text { Fatty acids } \\
\text { (range) }\end{array}$} & \multicolumn{4}{|c|}{ Tretman } \\
\hline & $I^{a}$ & $\mathrm{II}^{\mathrm{a}}$ & $1^{b}$ & $\mathrm{II}^{\mathrm{b}}$ \\
\hline C14:0 & $0,32 \pm 0,014^{\mathbf{e}, \mathbf{a}}$ & $0,35 \pm 0,02^{f}$ & $0,34 \pm 0,03$ & $0,43 \pm 0,02^{\mathbf{b}}$ \\
\hline C15:0 & $0,05 \pm 0,004^{\mathbf{a}}$ & $0,06 \pm 0,01^{b, e, ~ a ~}$ & $0,05 \pm 0,01^{\mathrm{f}, \mathrm{a}}$ & $0,13 \pm 0,03^{\mathbf{b}}$ \\
\hline C16:0 & $23,16 \pm 0,48^{\mathbf{a}, \mathbf{e}}$ & $24,36 \pm 0,51^{\mathbf{b}, \mathbf{a}}$ & $22,26 \pm 0,61^{\mathbf{f}, \mathbf{b}, \mathbf{a}}$ & $26,81 \pm 0,79^{\mathbf{b}}$ \\
\hline C16:1 & $4,34 \pm 0,35^{\mathbf{e}, \mathbf{a}}$ & $3,81 \pm 0,49^{f}$ & $3,54 \pm 0,14^{\mathbf{b}}$ & $3,85 \pm 0,72$ \\
\hline C17:0 & $0,09 \pm 0,01^{c, e, a}$ & $0,10 \pm 0,01^{d, a}$ & $0,10 \pm 0,01^{f, a}$ & $0,15 \pm 0,02^{\mathbf{b}}$ \\
\hline $\mathrm{C} 18: 0$ & $6,04 \pm 0,37^{\mathbf{a}}$ & $7,72 \pm 0,58^{\mathbf{b}, \mathbf{a}, \mathbf{c}}$ & $6,68 \pm 0,22^{\text {b, a }}$ & $8,76 \pm 0,78^{\mathbf{b}, \mathbf{f}}$ \\
\hline C18:1c-9 & $39,56 \pm 1,21^{c, a}$ & $38,06 \pm 1,40^{d, c}$ & $37,12 \pm 1,26^{\mathbf{b}, \mathbf{d}, \mathbf{c}}$ & $38,38 \pm 1,39^{\mathbf{d}}$ \\
\hline C18:2n6 & $23,22 \pm 1,14^{\mathbf{e}, \mathbf{a}}$ & $21,87 \pm 1,21^{\mathbf{f}, \mathbf{a}}$ & $25,83 \pm 0,87^{\mathbf{b}, \mathbf{a}}$ & $14,89 \pm 1,93^{\mathbf{b}}$ \\
\hline C18:3n6 & $0,19 \pm 0,05^{\mathbf{a}}$ & $0,22 \pm 0,04^{\mathbf{e}, \mathbf{a}}$ & $0,16 \pm 0,03^{f, a}$ & $0,01 \pm 0,03^{\mathbf{b}}$ \\
\hline$C 18: 3 n 3$ & $1,31 \pm 0,06^{\text {a, e }}$ & $1,09 \pm 0,08^{\mathbf{b}, \mathbf{a}}$ & $1,48 \pm 0,16^{\mathbf{f}, \mathbf{b}, \mathbf{a}}$ & $0,51 \pm 0,09^{\mathbf{b}}$ \\
\hline C20:0 & $0,07 \pm 0,03^{c}$ & $0,09 \pm 0,02^{d, ~ e ~}$ & $0,09 \pm 0,02^{c}$ & $0,06 \pm 0,02^{f, d}$ \\
\hline$C 20: 1$ & $0,49 \pm 0,03^{\mathbf{e}, a}$ & $0,46 \pm 0,01^{f, c, a}$ & $0,38 \pm 0,09^{\mathbf{b}, \mathbf{d}}$ & $0,39 \pm 0,03^{\mathbf{b}}$ \\
\hline$C 20: 2$ & $0,23 \pm 0,04^{\mathrm{a}}$ & $0,34 \pm 0,05^{\mathbf{b}}$ & - & $0,35 \pm 0,24$ \\
\hline$c 20: 3 n 6$ & $0,48 \pm 0,07^{c, a}$ & $0,43 \pm 0,02^{d, a}$ & $0,46 \pm 0,09^{\mathbf{a}}$ & $0,06 \pm 0,04^{\mathbf{b}}$ \\
\hline$C 20: 3 n 3$ & $0,005 \pm 0,01^{e, c}$ & $0,26 \pm 0,24^{f}$ & $0,24 \pm 0,31^{d}$ & - \\
\hline$C 22: 1+20: 4$ & $0,42 \pm 0,14^{c}$ & $0,80 \pm 0,43^{d}$ & $0,71 \pm 0,37^{d}$ & $0,64 \pm 0,20^{\mathbf{d}}$ \\
\hline$C 20: 5 n 3$ & $0,005 \pm 0,01^{c, e}$ & $0,035 \pm 0,03^{d}$ & $0,04 \pm 0,03^{f}$ & $0,025 \pm 0,03$ \\
\hline SFA & $29,68 \pm 0,53^{\mathbf{a}}$ & $32,60 \pm 0,75^{\mathbf{b}, \mathbf{a}}$ & $29,53 \pm 0,74^{\mathbf{b}, \mathbf{a}}$ & $40,87 \pm 2,98^{\mathbf{b}}$ \\
\hline MUFA & $44,43 \pm 1,34^{\mathbf{e}, ~ a, ~ c ~}$ & $42,34 \pm 1,83^{\mathbf{f}, \mathbf{c}}$ & $41,05 \pm 1,35^{\mathbf{b}, \mathbf{d}, \mathbf{e}}$ & $42,62 \pm 1,82^{\mathbf{d}, \mathbf{f}}$ \\
\hline PUFA & $25,46 \pm 1,21^{c, a}$ & $24,25 \pm 1,33^{\mathbf{d}, ~ a}$ & $28,69 \pm 0,87^{\mathbf{b}, \mathbf{a}}$ & $15,86 \pm 1,97^{\mathbf{b}}$ \\
\hline$n-3$ & $1,32 \pm 0,07^{\mathbf{a}}$ & $1,39 \pm 0,20^{\mathbf{e}, \mathbf{a}}$ & $1,92 \pm 0,38^{\mathbf{b}, \mathbf{f}, \mathbf{a}}$ & $0,54 \pm 0,09^{\mathbf{b}}$ \\
\hline$n-6$ & $24,13 \pm 1,16^{c, ~ a ~}$ & $22,86 \pm 1,25^{\mathbf{d}, \mathbf{a}}$ & $26,77 \pm 0,82^{\mathbf{b}, \mathbf{a}}$ & $15,32 \pm 1,94^{\mathbf{b}}$ \\
\hline$n-6 / n-3$ & $18,24 \pm 0,74^{\mathbf{e}, \mathbf{a}}$ & $16,75 \pm 1,85^{f, c}, \mathbf{a}$ & $14,40 \pm 2,88^{\mathbf{f}, \mathbf{d}, \mathbf{a}}$ & $29,01 \pm 5,34^{\mathbf{b}}$ \\
\hline PUFA/SFA & 0,857 & 0,744 & 0,97 & 0,39 \\
\hline MUFA/SFA & 1,50 & 1,30 & 1,39 & 1,04 \\
\hline
\end{tabular}

$n=12$ per Tretman, ${ }^{\text {a:b }} p<0,001$, c:d $p<0,05$, e:f $p<0,01$. 
Table 3 Fatty Acids Composition (mg/100 g) of Drumstick $(\bar{X} \pm \mathrm{Sd})$

\begin{tabular}{|c|c|c|c|c|}
\hline \multirow{2}{*}{$\begin{array}{l}\text { Fatty acids } \\
\text { (range) }\end{array}$} & \multicolumn{4}{|c|}{ Tretman } \\
\hline & $I^{a}$ & $I I^{a}$ & $\mathrm{I}^{\mathrm{b}}$ & $\mathrm{II}^{\mathrm{b}}$ \\
\hline C14:0 & $0,32 \pm 0,01^{\mathbf{a}}$ & $0,33 \pm 0,01^{\mathbf{a}}$ & $0,34 \pm 0,04^{c}$ & $0,38 \pm 0,03^{\mathbf{b}, \mathbf{d}}$ \\
\hline C15:0 & $0,047 \pm 0,00^{\mathbf{a}}$ & $0,05 \pm 0,02$ & $0,05 \pm 0,005^{\mathbf{b}, \mathbf{c}}$ & $0,07 \pm 0,01^{\mathbf{b}, \mathbf{d}}$ \\
\hline C16:0 & $23,03 \pm 0,85^{\mathbf{a}}$ & $23,22 \pm 1,01^{\mathbf{a}}$ & $21,52 \pm 0,63^{\mathbf{b}, \mathbf{a}}$ & $23,69 \pm 1,36^{\mathbf{b}}$ \\
\hline C16:1 & $4,38 \pm 0,36^{c, ~ a ~}$ & $4,06 \pm 0,48^{d, ~ c ~}$ & $3,80 \pm 0,22^{\mathbf{b}, \mathbf{d}, \mathbf{c}}$ & $4,40 \pm 0,67^{d}$ \\
\hline C17:0 & $0,09 \pm 0,00^{\mathbf{e}}$ & $0,10 \pm 0,01^{\mathbf{f}}$ & $0,09 \pm 0,00$ & $0,09 \pm 0,02$ \\
\hline C18:0 & $6,00 \pm 0,54^{a, c}$ & $6,93 \pm 0,53^{\mathbf{b}, \mathbf{a}}$ & $5,96 \pm 0,08^{\mathbf{b}, \mathbf{e}}$ & $6,90 \pm 0,79^{f}$ \\
\hline C18:1c-9 & $39,89 \pm 1,14^{c, e}$ & $38,69 \pm 0,98^{d, c}$ & $38,13 \pm 1,52^{\mathbf{f}, \mathbf{c}}$ & $39,26 \pm 0,76^{\mathbf{d}}$ \\
\hline $\mathrm{C} 18: 2 \mathrm{n} 6$ & $22,92 \pm 1,39^{\mathbf{a}}$ & $23,03 \pm 2,05^{\mathbf{a}}$ & $26,61 \pm 1,51^{\mathbf{b}, \mathbf{a}}$ & $22,22 \pm 1,99^{\mathbf{b}}$ \\
\hline $\mathrm{C} 18: 3 \mathrm{n} 6$ & $0,18 \pm 0,05^{\mathbf{a}}$ & $0,19 \pm 0,02^{\mathbf{e}, \mathbf{a}}$ & $0,16 \pm 0,02^{\mathbf{f}, \mathbf{a}}$ & $0,08 \pm 0,02^{\mathbf{b}}$ \\
\hline $\mathrm{C} 18: 3 \mathrm{n} 3$ & $1,27 \pm 0,10^{\mathbf{a}}$ & $1,23 \pm 0,12^{\mathbf{a}}$ & $1,55 \pm 0,12^{\mathbf{b}, \mathbf{a}}$ & $1,03 \pm 0,35^{\mathbf{b}}$ \\
\hline C20:0 & $0,07 \pm 0,03$ & $0,09 \pm 0,00^{\mathbf{a}}$ & $0,09 \pm 0,01^{\mathbf{a}}$ & $0,06 \pm 0,01^{\mathbf{b}}$ \\
\hline$C 20: 1$ & $0,47 \pm 0,04^{c}$ & $0,46 \pm 0,03^{c}$ & $0,43 \pm 0,06^{\mathbf{d}}$ & $0,36 \pm 0,12^{d}$ \\
\hline$C 20: 2$ & $0,24 \pm 0,04^{\mathbf{e}}$ & $0,30 \pm 0,04^{f, c}$ & - & $0,39 \pm 0,14^{f, d}$ \\
\hline$C 20: 3 n 6$ & $0,54 \pm 0,07^{\mathbf{e}, \mathbf{a}}$ & $0,45 \pm 0,04^{f, a}$ & $0,37 \pm 0,036^{\mathbf{b}}$ & $0,22 \pm 0,04^{\mathbf{b}}$ \\
\hline$C 20: 3 n 3$ & $0,02 \pm 0,02$ & $0,07 \pm 0,13$ & $0,07 \pm 0,15$ & - \\
\hline$C 22: 1+20: 4$ & $0,47 \pm 0,08^{\mathbf{a}}$ & $0,60 \pm 0,20^{c, e}$ & $0,39 \pm 0,21^{d}$ & $0,29 \pm 0,09^{\mathbf{b}, \mathbf{f}}$ \\
\hline$C 20: 5 n 3$ & - & $0,02 \pm 0,02^{\mathbf{e}}$ & $0,02 \pm 0,02^{\mathbf{e}}$ & $0,12 \pm 0,09^{f}$ \\
\hline SFA & $29,58 \pm 1,26^{\mathbf{c}, ~ e}$ & $30,92 \pm 1,39^{\mathbf{d}, ~ a ~}$ & $28,07 \pm 0,64^{f, ~ b, ~ a ~}$ & $31,60 \pm 1,84^{\mathbf{f}, \mathbf{b}}$ \\
\hline MUFA & $44,75 \pm 1,34^{\mathbf{c}, ~ a ~}$ & $43,17 \pm 1,44^{\mathbf{d}}$ & $42,37 \pm 1,61^{\mathbf{b}, \mathbf{a}}$ & $44,03 \pm 1,08^{\mathbf{b}}$ \\
\hline PUFA & $25,19 \pm 1,48^{\mathbf{a}}$ & $25,30 \pm 2,15^{\mathbf{a}}$ & $29,17 \pm 1,60^{\mathbf{b}, \mathbf{a}}$ & $24,07 \pm 2,33^{\mathbf{b}}$ \\
\hline$n-3$ & $1,29 \pm 0,08^{\mathbf{a}}$ & $1,32 \pm 0,14^{\mathbf{a}}$ & $1,72 \pm 0,17^{\mathbf{b}, \mathbf{a}}$ & $1,15 \pm 0,33^{\mathbf{b}}$ \\
\hline$n-6$ & $23,89 \pm 1,40^{\mathbf{a}}$ & $23,98 \pm 2,06^{\mathbf{a}}$ & $27,45 \pm 1,56^{\mathbf{b}, \mathbf{a}}$ & $22,92 \pm 2,04^{\mathbf{b}}$ \\
\hline$n-6 / n-3$ & $18,44 \pm 0,53^{\mathbf{a}}$ & $18,31 \pm 1,37^{\mathbf{e}}$ & $16,08 \pm 1,52^{\mathbf{b}, \mathbf{f}, \mathbf{e}}$ & $20,84 \pm 3,92^{f}$ \\
\hline PUFA/SFA & 0,85 & 0,82 & 1,04 & 0,76 \\
\hline MUFA/SFA & 1,51 & 1,39 & 1,51 & 1,39 \\
\hline
\end{tabular}

$\mathrm{n}=12$ per Tretman, ${ }^{\mathrm{a}: \mathrm{b}} \mathrm{p}<0,001,{ }^{\text {c:d }} \mathrm{p}<0,05,{ }^{\text {e:f }} \mathrm{p}<0,01$.

showed significant difference $(\mathrm{P}<0.001)$ between the products, varying from $54.13 \mathrm{mg} / 100 \mathrm{~g}$ to $111.64 \mathrm{mg} / 100 \mathrm{~g}$ in the drumsticks versus $53.71 \mathrm{mg} / 100 \mathrm{~g}$ to $99.8 \mathrm{mg} / 100 \mathrm{~g}$ in breast muscles. The total lipid content varied from $8.11 \%$ to $15 \%$ in drumstick, while in the breast was up to $7 \%$. Pearson correlation coefficients conducted due to water evaporation during roasted, showed moderate significant negative correlation between the content of moisture in raw and content of cholesterol in roasted meat in treatment I, while in treatment II varied from negative $(R=-0.236)$ to strong significant positive correlation $(R=0.638)$. A similar relationship was observed between the content of cholesterol and fats in roasted meat. The oxidative stability of roasted dark and white chicken meat was studied using the 2-thiobarbituric (TBA) (data not shown). Thigh muscle had higher concentrations (up to $8.63 \mathrm{mg} / \mathrm{MAL} / \mathrm{kg}$ ) of TBA than breast muscle (up to $5.52 \mathrm{mg} / \mathrm{MAL} / \mathrm{kg}$ ). This fact could be explain that thigh muscle had higher concentrations $(11.07 \%-14.73 \%)$ than breast $(3.57 \%-6.25 \%)$. There were significant negative interactions between content of TBA, cholesterol and fats in both muscles, except in one case in the breast and drumstick meat, where is a significant positive correlation was noted ( $R=0.256$ to 0.608 ).

\section{Discussion}

\section{Carcass quality}

Meat provides a good source of minerals and has a dual role in relation to daily iron supply due to the high bioavailability of haem iron in muscle tissue and the enhancing effect on the bioavailability of non-haem iron [19]. Thus, the percentage of iron that is heme is important in estimating the total bioavailable iron in foods. Heme iron values averaged $29 \%$ and $40 \%$ for breasts and drumstick chicken meat, respectively [20]. Recently, Wang et al. (2009) [21] found that pre-slaughter exposure to heat reduced the oxidative stability of broiler breast muscle protein, decreasing its functional properties. At the arrival at the abattoir, it has been observed that 
holding birds at different temperatures can influence some meat quality properties. There are reports of lower $\mathrm{pH}$ from birds kept at elevated temperatures compared to broilers held in cooler conditions [22]. McKee and Sams (1997) [23] observed that turkeys subjected to elevated temperatures prior to slaughter exhibited more PSE meat characteristics. Moreover, Warriss et al. (1999) [24] indicated that holding broilers for more than 1 hour prior to slaughter resulted in higher breast $\mathrm{pH}$ due to effects of glycogen muscle depletion. Water-holding capacity (WHC) is an important meat quality attribute because color, juiciness, and tenderness are all partially dependent on the ability of the meat to retain moisture under normal storage conditions and during thermal processing [25]. Water-holding capacity is also factor used for evaluating PSE meat. The results from this study indicate that variations in broiler meat $\mathrm{pH}$ and Water-holding capacity, could be related to differences in the shelf-life of the product. High muscle $\mathrm{pH}$ produced conditions that make dark-colored fillets more susceptible to bacterial spoilage than light-colored fillets when held at the same refrigerated storage conditions. It may be advantageous for industry to separate broiler meat according to color and to divert dark-colored fillets into further processed products where the shelf-life could be extended. However, it should be noted that during the cooking process, fillets that have a high muscle $\mathrm{pH}$ may result in a pink, undercooked appearance [26-28].

\section{Cholesterol concentration}

Cholesterol is an important molecule that has roles in membrane structure as well as being a precursor for the synthesis of molecules such as steroid hormones, vitamin D, and bile acids [29]. Furthermore, the lack of correlation or a weak correlation between the fat and cholesterol contents of meat reported in our study (Figure 2), is in line with what has been found in previous studies [30,31]. In regard to the effect of carcasse weight on total lipid and cholesterol content in meat, total lipid content in both muscles was independent of carcasse weight, while cholesterol content varied from moderate significant positive $(R=0.584)$ to high significant negative correlation $(\mathrm{R}=-0.660)$ (Figure $3 \mathrm{~A}, \mathrm{~B})$. The reason of these facts could be explained due to carcasses were taken within a wide range of weight (1021.7 to $2226.7 \mathrm{~g}$ ) to obtain sufficient variability of total lipid and consequently of cholesterol. It was shown that the subcellular distribution of cholesterol in muscle tissue changed as intramuscular fat increased but, this resulted in no overall change in the total cholesterol in the muscles [30]. A significant factor affecting the cholesterol content of poultry is presence of skin in many retail cuts. Poultry skin has the greatest cholesterol concentration compared with poultry meat or poultry fat. Chicken has also been shown to contain slightly higher cholesterol contents than beef and pork in other studies [30,32]. The differences in cholesterol content among different muscles of the same species and between the same muscles in different species are generally explained by variations in absorption and the biosynthesis of cholesterol, lipoprotein metabolism, diet, muscle fiber type distribution, genetic variation, subcutaneous and intramuscular fat, body weight $[13,14,16,33,34]$, as well as cell size. Cholesterol can be obtained directly from the diet, or it can be synthesized in cells from 2-carbon acetate groups of acetylcoenzyme A. Because the synthetic pathway is under feedback control of dietary cholesterol, the percentage of cholesterol arising from de novo biosynthesis or from the diet depends upon the amount of cholesterol that is ingested. Even when cholesterol intake is very low, de novo biosynthesis will enable the production of the cholesterol required to supply the large variety of biological processes in which this molecule is involved. The human diet nowadays usually includes excessive levels of cholesterol and saturated fat [35]. Various international institutions (e.g., World Health Organization) have drawn up nutritional recommendations that include limitations that refer not only to the amount of fat and the fatty acid composition, but also the cholesterol levels in foods, of which meat and meat products constitute a major part [7].

\section{Fatty acid composition of breast and drumsticks muscle}

Differences in tissue fatty acid profiles could be attributed to different roles of fatty acids in these tissues or to their different contents of phospholipids. PUFA are preferentially incorporated into phospholipids [36] and phospholipids are in higher proportion in muscle fat [37]. This study has clearly demonstrated that decreasing the dietary $n 6 / n 3$, increases the deposition of desirable $\mathrm{n} 3$ and n6 long chain PUFA in the edible tissue, thereby achieving nutritionally enriched meat. Meat has been implicated in imbalanced fatty acid intake by consumers, due to some meats naturally having a low PUFA to SFA ratio $(\mathrm{P} / \mathrm{S})$ ratio of around 0.1 . Thus a $\mathrm{P} / \mathrm{S}$ ratio of 0.4 is often recommended $[5,38]$. Also, it is recommended that dietary energy coming from fat for human consumption should not be more than $30 \%$, while the relation among SFA, MUFA and PUFA should equal 1:1:1 [39]. In the current study the $\mathrm{P} / \mathrm{S}$ ratio was higher than 0.4 , ranging between 0.39 to 0.97 in breast muscle versus 0.76 to 1.04 in drumsticks muscle. Recently, epidemiological studies suggested that the major risk factor for atherosclerosis and coronary heart diseases was found to be a high $n-6 / n-3$ ratio rather than a high intake of cholesterol and the consequent hypercholesterolemia [40]. In the present experiment, the higher $n-6 / n-3$ ratio indicating its potent role in defining the quality of broiler meat. 

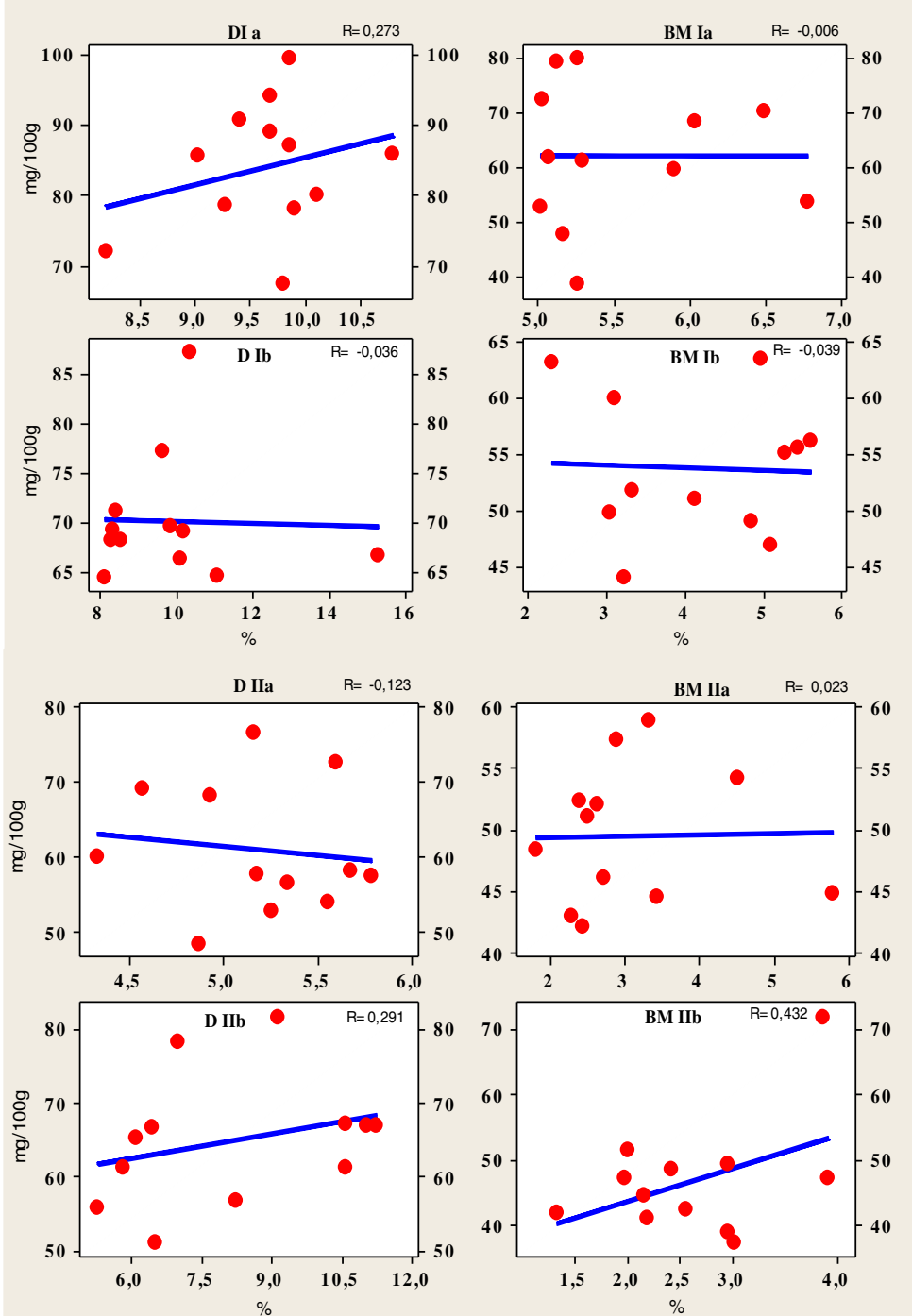

Figure 2 Pearson correlation between content of fats (\%) and cholesterol ( $\mathrm{mg} / 100 \mathrm{~g}$ ) in Breast and Drumstick muscle (D -Drumstick, BM - Breast muscle, l, II-farm, a Summer, b Autumn/winter period).

The saturated fatty acids (SFAs) in poultry tissues rely upon their presence in the diet and their synthesis in the liver [41]. The SFAs synthesis is inhibited in the liver more during digestion of unsaturated fats than saturated fats [42]. Also, the increase of PUFAs decreased the synthesis of monounsaturated fatty acids (MUFAs) by inhibiting the activity of 9-desaturase complex, which is the key enzyme needed to convert SFAs to MUFAs [43]. Our results supported recently, researchers that dietary polyunsaturated fatty acids decreased body fat deposition [44]. As noted earlier, the fatty acid composition of meat is influenced by factors other than diet including genotype, gender and age of the animal. Genetic factors affect the meat fatty acid composition, but to a lower extent than dietary factors [45]. Genetic variability relates to differences between species, between breeds or lines, variation due to the crossing of breeds and variation between animals within breeds.

The results of the current study indicated that the fatty acid profiles of broiler tissues may be customized by feeding a diet containing a lipid having the fatty acid composition desired of the resulting tissue. In view of concern over excessive SFA or PFA intakes by humans, possible future applications of these results include increasing the broiler tissue level of a specific fatty acid or mixture of fatty acids thought to be beneficial to human health (e.g., oleic acid or oleic acid plus omega-3 fatty acids). Additionally, manipulation of the tissue content of specific fatty acids may benefit producers of further processed products through better control of fat liquidity and susceptibility to lipid oxidation. This concept will provide broiler producers a means to customize 

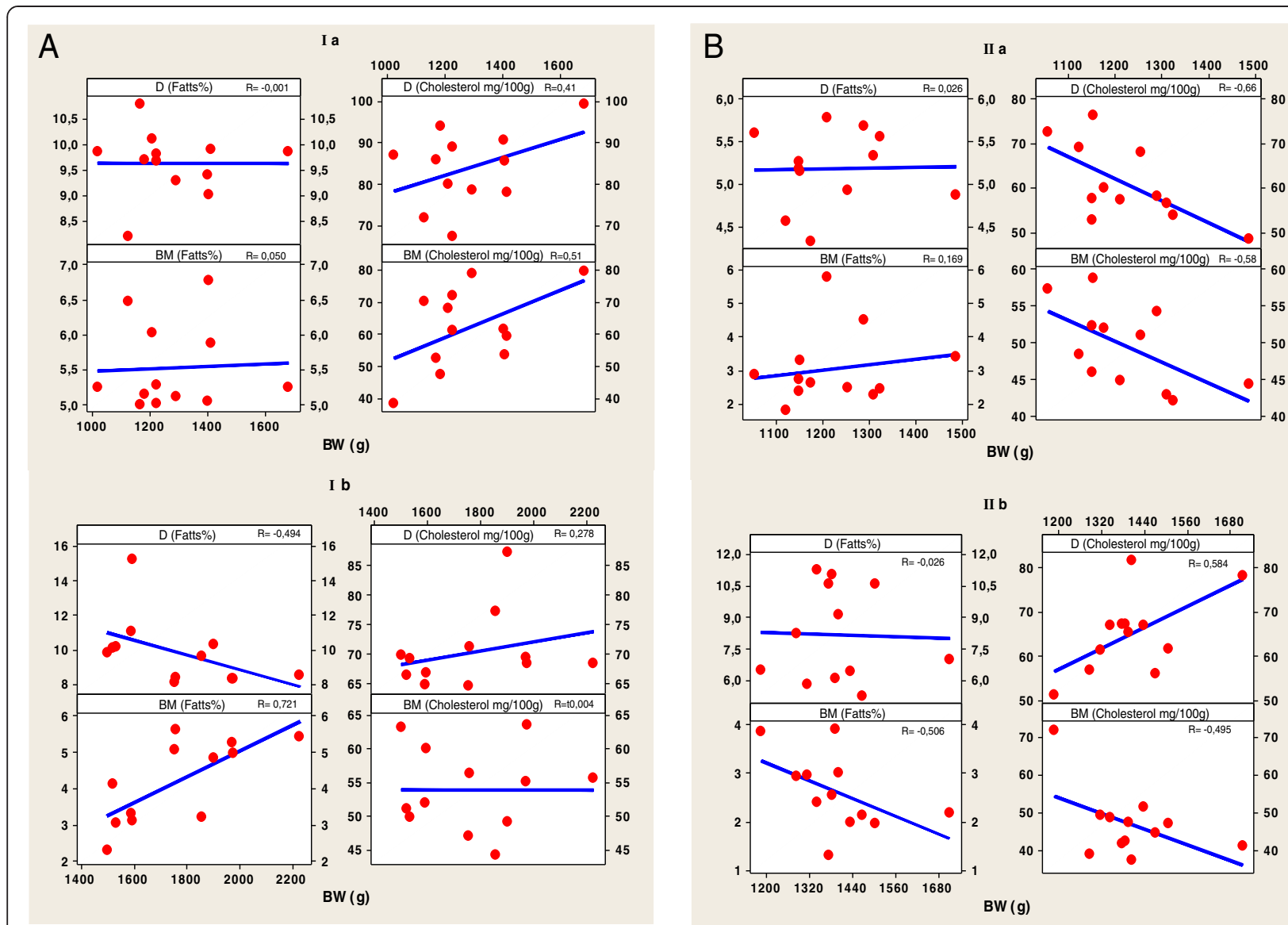

Figure 3 A. Pearson correlation between Carcass, weight (g), and content of fatts (\%) and cholesterol (mg/100 g) (D -Drumstick, B Breast muscle, I, II-farm, a Summer, b Autumn/winter period). B. Pearson correlation between Carcass, Breast muscle and Drumstick weight (g), and content of fatts (\%) and cholesterol (mg/100 g) (D -Drumstick, B - Breast muscle, I, II-farm, a Summer,

b Autumn/winter period)

their product more effectively compete with beef in fulfilling the demands of increasingly health-conscious consumers.

\section{Roasted meat}

Chicken meat is particularly susceptible to lipid oxidation as it has a high proportion of unsaturated fatty acids, and the formation of COP during storage or heatprocessing.appears to vary depending on the part of the chicken and the cooking method used $[8,46]$. The levels of COP reported in fresh or freshly processed chicken are generally low or undetectable $[8,46]$. On the other hand, cooking methods can increase significantly cholesterol oxidation up to $1.5 \%(\mathrm{COP} /$ cholesterol) in fried chicken patties [14], rising from 4 to 10 times the total COP content in cooked meat than in raw meat $[8,46]$. Grau et al. (2001) [47] has observed that the dietary lipid sources including beef tallow, fresh and oxidized sunflower oils did not have a considerable effect on the cholesterol content in raw chicken meat, whereas the content of cholesterol oxidation products was significantly higher only in the chickens fed with sunflower oil, reported in our study. Studies in rabbits, chicken, and other susceptible species showed that dietary cholesterol and oxycholesterols can lead to atherosclerosis [48-50]. Cholesterol and cholesterol oxidation products (COPs, oxycholesterols) are also known to be a risk factor for coronary heart disease (CHD) and COPs may have cytotoxic, mutagenic and atherogenic effects, and thus are harmful to humans [51].

\section{Conclusion}

In conclusion, chicken meat is characterized by high nutritive value. Due to low cholesterol, a fairly high protein and PUFA content, it can be used as a valuable inclusive component of the human diet, with potential health benefits. It is evident from this review of the scientific literature that additional research is required in several areas, notably: (1) the true impact of dietary fatty acid supplementation on animal health and welfare; (2) the impact 
of fatty acid enrichment of animal diets on production costs; (3) the effect of fatty acid changes on product shelf-life and quality.

In view of concern over excessive SFA or PFA intakes by humans, possible future applications of these results include increasing the broiler tissue level of a specific fatty acid or mixture of fatty acids thought to be beneficial to human health (e.g., oleic acid or oleic acid plus omega-3 fatty acids). Additionally, manipulation of the tissue content of specific fatty acids may benefit producers of further processed products through better control of fat liquidity and susceptibility to lipid oxidation.

\section{Methods}

\section{Experimental site}

The experiment was conducted on the (farm I- $45^{\circ} 44^{\prime} \mathrm{N}$, $20^{\circ} 72^{\prime} \mathrm{E}, 76 \mathrm{~m}$, farm II- $45^{\circ} 52^{\prime} \mathrm{N}, 1^{\circ} 27^{\prime} \mathrm{E}, 99 \mathrm{~m}$ ) province of Vojvodina, northern part of Serbia.

\section{Birds, management, and diets}

During the experimental period from June to November of 2012, and February of 2013, two homogeneous groups of male and female (50:50\%) mainly Ross 308 and partially Hubbard broilers, were reared under commercial conditions in two separate houses (20 000 animals per house) and were fed ad libitum a commercial diet. When the broilers were 38 days old, they were slaughtered at a commercial abattoir. Prior to slaughter, broiler was subjected to a total feed withdrawal of 8-12 $\mathrm{h}$, including a holding time at the processing plant of 2-3 h.

\section{Slaughter procedures}

On day 38 , the broilers, were stunned individually in a waterbath stunner $(2,7 \mathrm{~A}, 45 \mathrm{~V}, 380 \mathrm{~Hz}, 25 \mathrm{~s})$, slaughtered and bled at a local slaughterhouse, using standard industry procedures. After slaughtering and dressing, hot carcasses were chilled two hours at $4^{\circ} \mathrm{C}$. Carcasses $(\mathrm{n}=12$ per farm), were randomly collected and used for subsequent meat quality evaluation during the summer $(\mathrm{n}=24)$ and winter $(\mathrm{n}=24)$ season.

\section{Sample collection}

After chilling, all carcasses were placed in insulated polystyrene boxes on ice and transferred to the laboratory within $2 \mathrm{~h}$ of chilling. Then, carcasses were weighted and refrigerated for $24 \mathrm{~h}$. The breast with skin (m. pectoralis major) and drumstick meat with skin (muscles of regio tibio-femoralis) were cut and separated. Whole samples of both muscles (about $20 \mathrm{~g}$ ) were placed in open aluminium pans and roasted in an electric oven (pre-heated to $220^{\circ} \mathrm{C}$ ) for $30 \mathrm{~min}$. Total lipid and cholesterol content were determined in raw and roasted breast and drumstick meat with skin.

\section{Analytical procedures \\ Fatty acids}

Total lipids for fatty acids determination in meat samples, were extracted from the sample by accelerated solvent extraction (ASE 200, Dionex, Sunnyvale, CA) with a mixture of $\mathrm{n}$ - hexane and isopropanol (60:40, v/v) in $33 \mathrm{ml}$ extraction cell at $100^{\circ} \mathrm{C}$ and nitrogen pressure of $10.3 \mathrm{MPa}$ [52]. The solvent was removed under the stream of nitrogen at $50^{\circ} \mathrm{C}$ until dryness in solvent evaporator (SE 500, Dionex, Sunnyvale, CA). The fat extract was further used for fatty acids determination.

Total lipids were further converted to fatty acid methyl esters (FAMEs) by using $0.25 \mathrm{M}$ trimethylsulfonium hydroxide (TMSH) in methanol [53]. FAMEs were determined by capillary gas chromatography on GC Shimadzu 2010 (Kyoto, Japan) equipped with flame ionization detector and capillary HP-88 column $(100 \mathrm{~m} \times 0.25 \mathrm{~mm} \times$ $0.20 \mu \mathrm{m}, J \& W$ Scientific, USA). Separation and detection were performed under the following temperature program: initial temperature $125^{\circ} \mathrm{C}$, rate $10^{\circ} \mathrm{C}$ min- 1 to $175^{\circ} \mathrm{C}$, hold $10 \mathrm{~min}$, rate $5^{\circ} \mathrm{C}$ min -1 to $210^{\circ} \mathrm{C}$, hold $5 \mathrm{~min}$, rate $2^{\circ} \mathrm{C}$ min- 1 to final temperature of $230^{\circ} \mathrm{C}$, hold $12 \mathrm{~min}$. Total analysis time was $50.5 \mathrm{~min}$. The injector and detector temperatures were $250^{\circ} \mathrm{C}$ and $280^{\circ} \mathrm{C}$, respectively; split ratio 1:50; volume $1 \mu \mathrm{L}$; carrier gas, $\mathrm{N} 2,1.33 \mathrm{~mL} / \mathrm{min}$; makeup gas, $\mathrm{N} 2,30 \mathrm{~mL} / \mathrm{min}$; detector gases, $\mathrm{H} 2,40 \mathrm{~mL} / \mathrm{min}$; synthetic air, $400 \mathrm{~mL} / \mathrm{min}$. The chromatographic peaks in the samples were identified by comparing relative retention times of FAME peaks with peaks in Supelco 37 Component FAME mix standard (Supelco, Bellefonte, USA).

Moisture and ash content of meat samples were determined according to the ISO methods [54,55]. Nitrogen was measured according to the Kjeldahl method (TecatorKjeltec system 8400, Tecator Foss, Sweden) and protein was calculated as $N \times 6.25$. Total lipid content was determined by extraction of fat by petroleter (Soxhlet) after acid hydrolysis of samples [56]. All measurements were performed in triplicate.

\section{pH}

Muscle $\mathrm{pH}$ was determined using an Testo $^{\circ} 230$ meter (Lenzkirch, Germany), fitted with a combined glass electrode, previously calibrated at $\mathrm{pH} 4.0$ and 7.0 with standard buffers (Mallinckrodt Chemicals, Phillipsburgh, NJ, USA) stored at room temperature $\left(20^{\circ} \mathrm{C}\right)$. The $\mathrm{pH}$ values were determined by inserting the probe into the geometric center of the thickest part of the muscles. The average $\mathrm{pH}$ value was defined through 3 measurements of the same area, and the procedures used for determination were the same for all of the samples. The samples were stored at $4{ }^{\circ} \mathrm{C}$ before measuring the $\mathrm{pH}$ value at $24 \mathrm{~h}$ postmortem. 


\section{Water-holding capacity}

Water-holding capacity of muscle samples were performed using the methodology of Wierbicki and Deatherage (1958) [57]. Briefly, $300 \pm 5 \mathrm{mg}$ of fresh, muscle tissue were weighed onto a piece of Whatman No. 1 filter paper, which had been stored in a desiccator over saturated potassium chloride. The sample was then pressed at $345 \mathrm{~N} / \mathrm{cm}^{2}$ for $1 \mathrm{~min}$. Areas of the meat and moisture were traced and subsequently measured using a compensating planimeter (Planix 8; Sokkia Corp., Overland Park, KS, USA). All samples were run in duplicate, and the percentage of free water was calculated by the following equation: free water $(\%)=$ $((($ moisture surface area - meat surface area $) \times 61.1) /$ total moisture) $\times 100$, whereas the percentage of bound water was calculated by subtracting the free water from 100 .

\section{Cholesterol determination}

Cholesterol determination in the meat was determined after direct saponification (without prior lipid extraction) according to the method described by Maraschiello et al. (1996) [58] and followed by HPLC analysis; the data are expressed as $\mathrm{mg} / 100 \mathrm{~g}$ fresh meat. To ca. $100 \mathrm{mg}$ of each homogenized chicken muscle sample $2 \mathrm{ml}$ of $0,5 \mathrm{M}$ $\mathrm{KOH}$ in methanol was addeded and tubes were vortexed for $30 \mathrm{~s}$. The mixture was directly saponified at $80^{\circ} \mathrm{C}$ during $1 \mathrm{~h}$. After cooling, $2 \mathrm{~mL}$ of distilled water, saturated with $\mathrm{NaCl}$ was added. The tubes were vortexed for 30s followed by addition of $3 \mathrm{~mL}$ diethilether/hexane $(1: 1, \mathrm{v} / \mathrm{v})$ and centrifugated for $10 \mathrm{~min}$ at $300 \mathrm{~g}$. The upper phase was transferred to a clean tube and the ether/hexane extraction step was repeated twice. All three extracts were combined and evaporated to dryness under stream of nitrogen. The dry extracts were dissolved in $1000 \mu \mathrm{l}$ of mobile phase used for HPLC analysis and then immediately filtered: $10 \mu \mathrm{l}$ was injected into HPLC. Cholesterol determination in the extract (from direct saponification, describe above) was performed by using HPLC/PDA system (Waters 2695 Separation module/Waters photodiode array detector, USA), on a Phenomenex Luna C 18 reverse/phase column, $150 \mathrm{~mm} \times 3,0 \mathrm{~mm}, 5 \mu \mathrm{m}$ particle size with $\mathrm{C} 18$ analytical guard column, $4.0 \mathrm{~mm} \times 2.0 \mathrm{~mm}$, at room temperature. The injected volume was $10 \mu \mathrm{L}$ The mobile phase was isopropanol-acetonitrile $(20: 80, \mathrm{v} / \mathrm{v})$ at a flow rate of $1.2 \mathrm{ml} \mathrm{min}^{-1}$, isocraticaly. Detection was performed at $210 \mathrm{~nm}$. Total analysis time lasted $10 \mathrm{~min}$. Quantification of cholesterol was done by external standardization in a linear concentration range from $25 \mathrm{mg} / 100 \mathrm{~g}$ to $125 \mathrm{mg} /$ $100 \mathrm{~g}$. Recoveries of the spiked quantities ranged from 66.30 to $74.80 \%$. Empower Pro software was used to control the HPLC system as well as for data acquisition and data processing.

\section{Iron determination}

Determinations of Fe in meat samples were performed by flame atomic absorption spectrophotometry (Analyst 300, Perkin Elmer, USA) following the methods described by Jorhem (2000) [59]. All reagents were of analytical grade, and MilliporeMilliQ deionized water was used throughout the procedures. Glass and polyethylene materials were soaked in $\mathrm{HNO}_{3}$ (Merck, Argentina) and washed with deionized water. Standard solutions of $\mathrm{Fe}$ (Perkin Elmer, USA) were prepared immediately before use by dilution (with deionized water) of a $1000 \mathrm{mg} / \mathrm{l}$ standard solution. Quality control was performed by running bovine liver standard (NIST standard, SRM 1577c, Gaithersburg, USA). Iron contents was expressed in $\mathrm{mg} / \mathrm{kg}$ of wet tissue.

\section{Statistical analysis}

The statistical analysis was performed with a Minitab 16.1.0.0 (Minitab Inc. (c) USA). The farms was used as the experimental unit for all the analyses done. Data are presented as mean \pm standard deviation (SD) for each treatment. For comparison between treatments, data were analyzed for normal distribution by KolmogorovSmirnov and equal variance by Kruskal-Wallis One Way Analysis of Variance (ANOVA procedure, SAS Inst. Inc., Cary, NC). When significant differences were identified among treatment means, they were separated using Tukey's Honestly Significant Difference test $(\mathrm{P}<0.05)$.

\section{Abbreviations}

HPLC/PDA: HPLC Photo Diode Array; CVD: cardiovascular disease; SFA's: saturated fatty acids; UFA: unsaturated fatty acids; PUFA's: polyunsaturated fatty acids; TBARS: Thiobarbituric acid reactive substances; WHC: Water-holding capacity; PSE: Pale, soft, and exudative.

\section{Competing interests}

The author's declare that they have no competing interests.

\section{Authors' contributions}

DM completed the project, established the study, analyzed the data, wrote the manuscript, and contributed to reviewing/editing the manuscript. DV, ZM and JNT have made substantial contributions to conception and design of the study, participated in the discussion and critically revised the manuscript. DT, NP and ZP performed statistical analyse, contributed to assay, researched and evaluated the literature. All authors read and approved the final manuscript.

\section{Acknowledgements}

This study was funded by the grants from the Institute of meat Hygiene and Technology and Ministry of Education, Sciences and Technological Developments of Republic Serbia.

\section{Author details}

Institute of Meat Hygiene and Technology, Kaćanskog 13, 11040 Belgrade, Serbia. ${ }^{2}$ Scientific Veterinary Institute "Novi Sad" Rumenički put 20, 21000 Novi Sad, Serbia. ${ }^{3}$ Department of Animal nutrition and botany, Faculty of Veterinary Medicine - University of Belgrade, 18 Bulevar oslobođenja, 11000 Belgrade, Serbia.

Received: 11 February 2014 Accepted: 25 February 2014 Published: 3 March 2014 


\section{References}

1. Simopoulos AP: Omega-3fatty acids in inflammation and autoimmune diseases. J Am Coll Nutr 2002, 21(6):495-505.

2. Simopoulos AP: Omega-6/omega-3 essential fatty acid ratio and chronic diseases. Food Rev Int 2004, 20:77-90.

3. Michikawa M: The role of cholesterol in pathogenesis of Alzheimer's disease: dual metabolic interaction between amyloid beta-protein and cholesterol. Mol Neurobiol 2003, 27:1-12.

4. World Health Organisation (WHO): Diet, Nutrition, and the Prevention of Chronic Diseases. In Report of a WHO Study Group. Geneva: World Health Organization; 1990:100-111.

5. Wood JD, Richardson RI, Nute GR, Fisher AV, Campo MM, Kasapidou E, Sheard PR, Enser M: Effect of fatty acids on meat quality: a review. Meat Sci 2003, 66:21-32.

6. Wood J, Enser M, Scollan N, Gulati S, Richardson I, Nute G: The Effects of Ruminally Protected Dietary Lipid on the Lipid Composition and Quality of Beef Muscle. In Proceedings of the 47th International Congress of Meat Science and Technology, Volume 1. Warszawa: Meat and Fat Research Institute; 2001:186-187.

7. Komprda T, Zelenka J, Fajmonová E, Bakaj P, Pechová P: Cholesterol content in meat of some poultry and fish species as influenced by live weight and total lipid content. J Agric Food Chem 2003, 51(26):7692-7697.

8. McCance R, Holland B, McCance W's: The Composition of Foods. 5th edition. Cambridge, U.K: The Royal Society of Chemistry and Ministry of Agriculture, Fisheries and Food; 1991

9. Woelfel R, Owens C, Hirschler E, Martinez-Dawson R, Sams A: The characterization and incidence of pale, soft, and exudative broiler meat in a commercial processing plant. Poult Sci 2002, 81:579-584.

10. Husak R, Sebranek J, Bregendahl K: A survey of commercially available broilers marketed as organic, free-range, and conventional broilers for cooked meat yields, meat composition, and relative value. Poult Sci 2008, 87:2367-2376

11. Vimini RJ: Overview of a Typical Poultry Meat in Relation to PSE Pork from a Global Level. Abstract 2-1. In Abstract 2-1 in: 1996 IFT Annual Meeting, New Orleans, LA. Chicago, IL: IFT; 1996.

12. Barbut S: Estimating the magnitude of the PSE problem in poultry. J Muscle Foods 1998, 9:35-49.

13. Komprda T, Zelenka J, Bakaj P, Kladroba D, Blažková E, Fajmonová E: Cholesterol and fatty acid content in meat of turkeys fed diets with sunflower, linseed or fish oil. Arch. Geflu" gelk 2003, 67:65-75.

14. Chizzolini R, Zanardi E, Dorigoni V, Ghidini S: Calorific value and cholesterol content of normal and low-fat meat and meat products. Trends Food Sci Technol 1999, 10:119-128.

15. Valsta LM, Tapanainen H, Mannisto S: Meat fats in nutrition. Meat Sci 2005, 70:525-530

16. Bragagnolo N: Cholesterol and Cholesterol Oxides in Meat and Meat Products. In Handbook of Muscle Foods Analysis. Edited by Nollet LML, Toldra F. Florida: CRC Press; 2009:187-219.

17. Honikel KO: Composition and Calories. In Handbook of Processed Meats and Poultry Analysis. Edited by Nollet LML, Toldra F. Florida: CRC Press; 2009:195-213.

18. Lopez-Ferrer S, Baucells MD, Barroeta AC, Grashorn MA: $n-3$ enrichment of chicken meat using fish oil: alternative substitution with rapeseed and linseed oils. Poult Sci 1999, 78:356-365.

19. Björn-Rasmussen E, Hallberg L: Effects of animal proteins in the absorption of food iron in man. Nutr Metab 1979, 23:192-202.

20. Clark EM, Mahoney AW, Carpenter CE: Heme and total iron in ready-to-Eat chicken. J Agric Food Chem 1997, 45(1):124-126.

21. Wang RR, Pan XJ, Peng ZQ: Effects of heat exposure on muscle oxidation and protein functionalities of pectoralis majors in broilers. Poultr Sci 2009, 88:1078-1084

22. Petracci M, Fletcher DL, Northcutt JK: The effect of holding temperature on live shrink, yields and breast meat quality of broiler chicken. Poult Sci 2001, 80:670-675.

23. Mckee SR, Sams AR: The effect of seasonal heat stress on rigor development and the incidence of pale, exudative turkey meat. Poult Sci 1997, 76:1616-1620

24. Warriss PD, Kestin SC, Brown SN, Belvis EA: Depletion of glycogen reserves in fasting broiler chickens. Br Poult Sci 1988, 29:149-154.

25. Jeffery AB: Principles of water-holding capacity applied to meat technology. J Sci Food Agric 1983, 34:1020-1021.
26. Schmidt G, Trout G: pH and color. Meat Ind 1984, 30(8):33-34

27. Trout GR: Variation in myoglobin denaturation and color of cooked beef, pork, and turkey meat as influenced by $\mathrm{pH}$, sodium chloride, sodium tripolyphosphate and cooking temperature. J Food Sci 1989, 54:536-544.

28. Yang $\mathrm{CC}$, Chen TC: Effects of refrigerated storage, $\mathrm{pH}$ adjustment, and marinade on color of raw and microwave cooked chicken meat. Poultr Sci 1993, 72:355-362.

29. Dessi S, Batetta B: Overview —Intracellular Cholesterol Homeostasis: Old and New Players. In Cell Growth and Cholesterol Esters. Edited by Pani A, Dessi S. New York: Kluwer Academic/Plenum Publishers; 2003:1-12.

30. Hoelscher LM, Savell JW, Smith SB, Cross HR: Subcellular distribution of cholesterol within muscle and adipose tissues of beef loin steaks. J Food Sci 1988, 53:718-722.

31. Honikel KO, Arneth W: Cholesterol in meat and eggs. Fleischwirtschaft 1996, 12(1244):1246-1248. 1253, 1329

32. Buege DR, Ingham BH, Henderson DW, Watters SH, Borchert LL, Crump PM, Hentges EJ: A nationwide audit of the composition of pork and chicken cuts at retail. J Food Comp Anal 1998, 11:249-261.

33. Salvatori G, Pantaleo L, Di Cesare C, Maiorano G, Filetti F, Oriani G: Fatty acid composition and cholesterol content of muscles as related to genotype and vitamin E treatment in crossbred lambs. Meat Sci 2004, 67:45-55.

34. Padre RG, Aricetti JA, Moreira FB, Matsushita M, de Souza NE, Visentainer JV, Do Prado IN, Mizubuti IY: Fatty acid profile, chemical composition of longissimus muscle of bovine steers and bulls finished in pasture system. Meat Sci 2006, 74:242-248.

35. Wang Y: Child Obesity and Health. In International Encyclopedia of Public Health. Edited by Heggenhougen K, Quah SR. Oxford: Academic Press; 2008:590-604.

36. Whitehead CC: Essential Fatty Acids in Poultry Nutrition. In Fats in Animal Nutriton. Edited by Wiseman J. London, UK: Butterworths; 1984:153-166.

37. Enser M: The Chemistry, Biochemistry and Nutritional Importance of Animal Fats. In Fats in Animal Nutriton. Edited by Wiseman J. London, UK: Butterworths; 1984:23-51.

38. Raats JG, Muchenje V, Dzama K, Chimonyo M, Strydom PE, Hugo A: Some biochemical aspects pertaining to beef eating quality and consumer health: a review. Food Chem 2009, 112:279-289.

39. Grashorn MA: Functionality of poultry meat. J Appl Poultr Res 2007, 16:99-106.

40. Enser M, Hallett K, Hewett B, Fursey GAJ, Wood JD, Harringhton G: Fatty acid content and composition of UK beef and lamb muscle in relation to production system and implications for human nutrition. Meat Sci 1998, 49:329-341.

41. Sheehy PJA, Morissey PA, Flynn A: Influence of heated vegetable oils and a-tocopheryl acetate supplementation on a-tocopherol, fatty acids and lipid peroxidation in chicken muscles. Br Poult Sci 1993, 34:367-381.

42. Sim JS, Qi GH: Designing Poultry Products using flaxseed. In Flaxseed in Human Nutrition. Edited by Cunnane C, Thompson LU, Flax S. Champaign, IL: AOCS Press; 1995:315-333.

43. Pinchasov Y, Nir l: Effect of dietary polyunsaturated fatty acid concentration on performance, fat deposition, and carcass fatty acid composition in broiler chickens. Poult Sci 1992, 71:1504-1512.

44. Crespo N, Esteve-Garcia E: Dietary polyunsaturated fatty acids decrease fat deposition in separable fat depots but not in the remainder carcass. Poult Sci 2002, 81:512-518.

45. De Smet S, Raes K, Demeyer D: Meat fatty acid composition as affected by fatness and genetic factors: a review. Anim Res 2004, 53:81-89.

46. Eder K, Grünthal G, Kluge H, Hirche F, Spilke J, Brandsch C: Concentrations of cholesterol oxidation products in raw, heatprocessed and frozenstored meat of broiler chickens fed diets differing in the type of fat and vitamin E concentrations. Br J Nutr 2005, 93:633-643.

47. Grau A, Codony R, Grimpa S, Baucells MD, Guardiola F: Cholesterol oxidation in frozen dark chicken meat: influence of dietary fat source and a-tocopherol and ascorbic acid supplementation. Meat Sci 2001, 57:197-208.

48. Moghadasian MH: Experimental atherosclerosis: a historical overview. Life Sci 2002, 70:855-865.

49. Staprans I, Pan XM, Rapp JH, Feingold KR: Oxidized cholesterol in the diet is a source of oxidized lipoproteins in human serum. J Lipid Res 2003, 44:705-715. 
50. Hur SJ, Du M, Nam K, Williamson M, Ahn DU: Effect of dietary fats on blood cholesterol and lipid and the development of atherosclerosis in rabbits. Nutr Res 2005, 25:925-935.

51. Schroepfer GJ: Oxysterols: modulators of cholesterol metabolism and other processes. Physiol Rev 2000, 80:361-554.

52. Spirić A, Trbović $D$, Vranić $D$, Đinović J, Petronijević $R$, Matekalo-Sverak $V$ : Statistical evaluation of fatty acid profile and cholesterol content in fish (common carp) lipids obtained by different sample preparation procedures. Anal Chim Acta 2010, 672:66-71.

53. EN ISO 5509: Animal and Vegetable Fats and Oils - Preparation of Methyl Esters of Fatty Acids. Belgrade, Serbia: Institute for Standardization of Serbia; 2000.

54. ISO 1442: Meat and Meat Products - Determination of Moisture Content (Reference Method). Belgrade, Serbia: Institute for Standardization of Serbia; 1997.

55. ISO 936: Meat and Meat Products - Determination of Total Ash. Belgrade, Serbia: Institute for Standardization of Serbia; 1998

56. ISO 1443: Meat and Meat Products - Determination of Total Fat Content. Belgrade, Serbia: Institute for Standardization of Serbia; 1973.

57. Wierbicki E, Deatherage FE: Determination of waterholding capacity of fresh meats. J Agric Food Chem 1958, 6:387-392.

58. Maraschiello C, Esteve E, Regueiro J, García A: Cholesterol oxidation in meat from chickens fed R-tocopherol- and a-carotene supplemented diets with different unsaturation grades. Lipids 1998, 33:705-713.

59. Jorhem $L$ : Determination of metals in foods by atomic absorption spectrometry after dry ashing: NMKL collaborative study. J AOAC Int 2000, 83:1204-1211.

doi:10.1186/1476-511X-13-42

Cite this article as: Milićević et al: The role of total fats, saturated/ unsaturated fatty acids and cholesterol content in chicken meat as cardiovascular risk factors. Lipids in Health and Disease 2014 13:42.

\section{Submit your next manuscript to BioMed Central and take full advantage of:}

- Convenient online submission

- Thorough peer review

- No space constraints or color figure charges

- Immediate publication on acceptance

- Inclusion in PubMed, CAS, Scopus and Google Scholar

- Research which is freely available for redistribution 